\title{
AN AUTOREGRESSIVE DISTRIBUTIVE LAG ANALYSIS OF CRIME \& TOURISM IN THE WESTERN CAPE PROVINCE, SOUTH AFRICA
}

\author{
Rufaro GARIDZIRAI* \\ Walter Sisulu University, Department of Management, South Africa, e-mail: rgaridzirai@wsu.ac.za
}

\begin{abstract}
Citation: Garidzirai, R. (2021). AN AUTOREGRESSIVE DISTRIBUTIVE LAG ANALYSIS OF CRIME \& TOURISM IN THE WESTERN CAPE PROVINCE, SOUTH AFRICA. GeoJournal of Tourism and Geosites, 35(2), 304-308. https://doi.org/10.30892/gtg.35206-652
\end{abstract}

\begin{abstract}
The relationship between crime and tourism has not received much attention in the academic fraternity. Instead, extensive attention has been placed on the impact of tourism on economic growth, inequality, poverty and employment. To contribute to the scarce literature on crime-tourism, the researcher examined the impact of crime on tourists arrival in the Western Cape Province, South Africa. An Autoregressive Distributive Lag model was employed to examine whether crime reduces or increases the arrival of tourists in the Western Cape Province. The results show that robberies, car hijacking and unemployment minimizes the number of tourists in the province, while economic growth and prosecution per population increases the number of tourists in the province. The results further highlight that robberies, car hijacking and unemployment disequilibrium can be solved after 1 year 6 months, holding all other things constant. Based on these findings, the study recommends that the government provide more employment opportunities to prevent crime in the province.
\end{abstract}

Key words: tourism arrival, crime, autoregressive distributive lag, Western Cape, time-series

$* * * * * *$

\section{INTRODUCTION}

The tourism sector has transformed into one of the most performing sectors worldwide. Its activities have surpassed the automobiles, food and oil exports industries, combined, in the past two decades (World Tourism Organisation, 2020). Thus, the sector has become a force to be reckoned with, despite the economic instabilities facing the world today. The success of the tourism sector is associated with the commitment of transferring the factors of production from traditional sectors to modern sectors (Garidzirai and Meyer, 2019). This also goes hand in glove with a rising multifariousness and contest among tourism destinations (World Tourism Organisation, 2020). Unquestionably, the growth of the tourism sector has provided positive externalities to other economic sectors such as agriculture, manufacturing and mining sector. This is explained by the money that circulates from the tourism sector to other economic sectors, thereby improving economic growth and employment in these sectors (Garidzirai and Moyo, 2020).

The demand for tourism is fast-growing and often interlinked with an increase in crime rates. Tourism proponents posit that the sector is sensitive to crime which poses substantial mental, material, emotional, and physical harm on tourists (Altindag, 2014; Mudzanani, 2017). More harm is, however, suffered by the society at large as crime increases distrust, intolerance and discourages social cohesion (Vila, 1994). The author further substantiates that tourists prioritize security issues when making a vacation choice as the majority of them are derive total satisfaction from positive aspects of life. Indeed, much attention should be given to the safety of the tourists so as to attract both domestic and international tourists (Mataković and Mataković, 2019).

The main research problem emanates from the fact that crime is a ubiquitous danger to South Africa. South Africa remains one of the countries with a high crime rate worldwide. Currently, the crime rate in South Africa is 78\%, and it is expected to increase in future (South African Police Services, 2019). Regrettably, the majority of these crimes are committed in the Western Cape province, which is the focus area of this study. The South African Police Services (2019) has reported that crime in the province has been increasing by an average of 5\% in the last two decades. This includes crimes such as common assault, robbery, car hijacking, drug-related crime, to mention a few. The government has attempted to reduce crime to no avail. Noteworthy is that the province is the most preferred tourist destination, therefore analyzing the relationship between crime and tourism arrival is vital for tourism policies and the increase in the body of knowledge on tourism.

Given the substantial harm crime can cause on tourism, the current study investigated the impact of crime on tourists arrivals in the Western Cape Province. Noteworthy is that a majority of studies have focused on the effects of crime on the economy (Altindang, 2014; Garidzirai and Nguza, 2020; Garidzirai and Moyo, 2020), while a handful of studies have focused on crime and tourism (Baker and Stockton, 2014; Mudzanani, 2017; Troy, 2013). The researcher has identified this research lacuna and emphasized that there is a lack of academic inquiry into the crime-tourism relationship. This implies that the crimetourism relationship is inadequate and infrequent. Therefore, the current study analyzed the impact of crime on tourism in the Western Province, South Africa, as it sought to make two contributions. First, the literature on crime-tourism is on panel data, and few/no studies are on the provincial level. For that reason, the study provides this relationship on a provincial level. Second, to the best knowledge of the scholar, this study is the first study in South Africa that has analyzed such a relationship using an econometric model as the few studies that have been conducted on a municipality level are descriptive (Mudzanani,

\footnotetext{
" Corresponding author
} 
2017; Nkosi, 2010). The current study will use variables such as car hijacking, robbery and prosecution per population. The study further used unemployment rate and economic growth as control variables.

\section{LITERATURE REVIEW}

The relationship between crime and tourism arrival can be explained by the routine activity theory. The theory posits a positive relationship between crime activities and tourism arrivals (Cohen and Felson, 1979). This implies that an increase in the number of visitors in a destination city increases crimes such as murder, robbery, car hijacking and violence. These crimes are treated as everyday activities that have become a routine behaviour in the host destinations. On the other hand, a city without crime is likely to attract crime when the number of visitors increases (Roncek and Maier, 1991). The routine activity theory makes three assumptions on how tourists arrival and crime relate (Brás, 2015). First, the theory postulates that tourists are a target of those who are motivated to commit crime specifically in less developed countries. Criminals are driven to commit crime because of massive income inequality where the poor envy those who have. Second, criminals target tourists valuable goods and services. In most destination cities, tourists carry their valuables with them which makes them easy targets for criminals. Third, the theory postulates that tourists are vulnerable as they do not have adept guardians. Tourists will be in an unknown environment, far from security or police, which makes it difficult for them to protect themselves (Pizam and Mansfeld, 2006).

The relationship between crime and tourism arrival cannot be separated from previous studies (Altindag, 2014: Baker and Stockton, 2014; Biagi et al., 2012; Mataković and Mataković, 2019; Mudzanani, 2017). For instance, Biagi et al., (2012) investigated the effects of tourism on crime from 1985-2003 using the systematic GMM methodology. The authors objective was to check if the crime rate recorded in Italy was a result of the inflow of tourists. The results reveal a positive influence of tourists on crime in a destination country. The results further highlight that the increase in total population influences crime in relation to the number of tourists in the country. Similar results were also found by Troy (2013) who studied the effects of crime on tourism arrival in Barbados using a transfer function methodology. The results reveal a negative impact of crime on tourists arrival. Thus, an increase in the crime rate leads to a decline in the number of tourists in an area.

Making use of panel analysis, Altindang (2014) examined the relationship between crime and international tourism in European countries. The author measured crime using violence and the risk of victimization, while the number of international tourists and revenue was used to measure tourism. It was found that international tourists are elastic to violent crimes compared to the risk of victimization. The result further highlights a decline in tourism revenue as a result of tourists responding to crime. In South Africa, Mudzanani (2017) conducted a thematic analysis of newspapers on how crime is a barrier to tourism in South Africa. The results highlight that robbery is one of the greatest threats to tourists in South Africa. Garidzirai and Zhanje (2019) further submitted that people commit crime as a result of lack of development in a country. Thus, a negative relationship between crime and economic growth is expected. Improved economic growth creates more employment that will reduce the crime rate in the country. This notion was emphasized by Statistics South Africa (2020).

A study was conducted in Honolulu and Las Vegas on the impact of crime on tourists arrival (Baker and Stockton, 2014). The authors used a panel analysis and found a negative relationship between violent crimes and the number of tourists in Honolulu, while in Las Vegas, a positive link between crime and the number of tourists was established. In Croatia, Mataković and Mataković (2019) examined the impact of crime on security in tourism using a descriptive analysis. The objective of the study was to find out if crime plays a significant role on security in tourism. The results show that crime has a negative influence on the destination image; therefore, a decrease in the number of tourists.

From the literature reviewed, the studies that examined crime and tourism are scarce and Europe based. A few studies done on this relationship in South Africa are questionnaire-based and qualitative in nature. To contribute to this scant literature, the current study examined the relationship between tourism and crime using the ARDL model, which provides robust and accurate results. The following section discusses the methodology and data used in this study.

\section{MATERIALS AND METHODS}

\section{Data Description}

A quantitative approach was used to examine the impact of crime on tourism arrival. Since the study population is the Western Cape province, a time series analysis was employed from 1994-2019. A sample size of 25 was deemed fit in timeseries, especially when employing an Autoregressive distributive lag (Pasara and Garidzirai, 2020). The time-series data used includes international tourism arrival, unemployment rate, prosecution per population, economic growth, number of car hijacking and robbery. Data for car hijacking, robbery and prosecution per population was obtained from the South African Police Services (2020), while data for unemployment rate and economic growth was obtained from the Global insight. International tourism arrival data was obtained from Statistics South Africa (2020).

Worth mentioning is that international tourism was used as a dependent variable. In contrast, unemployment rate, economic growth, number of car hijacking, robbery and prosecution per population were used as independent variables. The model describing this relationship is shown in equation 1.

$$
\text { Inltour }_{\mathrm{t}}=\beta_{0}+\beta_{1} \text { lnro }_{\mathrm{t}}+\beta_{2} \operatorname{lnhij}_{\mathrm{t}}+\beta_{\mathrm{a}} \operatorname{lnpros}_{\mathrm{t}}+\beta_{4} \operatorname{lnump}_{\mathrm{t}}+\beta_{5} \operatorname{lngdp}_{\mathrm{t}}+\varepsilon_{\mathrm{t}}
$$

Where lnItour represents the number of international tourists arrival, lnrob is the number of robbery cases in the Western Cape province; Inhij is the number of car hijacking in the province and lnpros is the number of prosecution per population in the Western Cape province. Furthermore, lnump is the unemployment rate in the province, while lngdp is the economic growth in the province. 


\section{Definition of variables and priori expectation}

Tourists arrival was used as a dependent variable. It is defined as the number of people visiting the Western Cape for holiday purposes (World Bank, 2019). Tourism arrival will depend on number of car hijacking, robbery, economic growth, unemployment and prosecution per population. Car hijacking and robbery are the number of crimes committed on car hijacking and robbery, respectively (Adekoya and Razaq, 2017). Both car hijacking and robbery are expected to decrease the number of tourists arrival in the province. Unemployment is expected to increase the crime rate in the province, thus, reducing the number of tourists in the province. Pasara and Garidzirai (2020) defined unemployment rate as all individuals who are actively looking for employment and cannot find a job. Economic growth is the increase in the Gross Domestic Product, considering the number of people in the country (Kathena and Shefeeni, 2017). Economic growth is expected to increase the number of tourists in the province. Prosecution per population is the number of people prosecuted after committing a crime in the Western Cape Province (SAPS, 2019). This variable is expected to decrease the crime rate in the province and increase the number of tourists in the province.

\section{Econometrics Procedure}

The study utilized four econometric procedures such as unit root test, cointegration, ARDL model and post-estimation tests. The unit root test is the first procedure employed to assess whether variables are stationary or not. The test is also used to determine the appropriate methodology to use (Gujarati, 2015). In achieving this aim, an Augmented Dickey Fuller (ADF) was used, and the rule of thumb is to accept the null hypothesis if the probability values are above $10 \%$. If the variables are a combination of 0 and 1 then an ARDL is deemed fit, while VAR and VECM can be used when variables are stationary at level one. The second step is to carry out a cointegration test to check whether a long-run relationship exists between crime and tourism arrival. An ARDL Bound cointegration test was employed and it is based on the F-statistic. Pesaran and Shin (1999) posit that the calculated F-statistic should be higher than the upper critical values for cointegration to exist. If the cointegration exists an ARDL model is employed and it is illustrated in equation 2 using the Pesaran and Shin (1998).

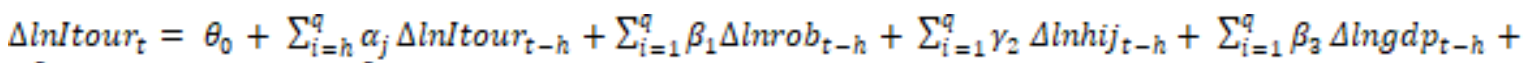

$$
\begin{aligned}
& \sum_{i=1}^{q} \beta_{3} \Delta_{\text {lnpros }_{\mathrm{t}-h}}+\sum_{\mathrm{i}=1}^{\mathrm{q}} \beta_{\mathrm{a}} \Delta \text { lnunm }_{\mathrm{t}-\mathrm{h}}+\varepsilon_{\mathrm{t}}
\end{aligned}
$$

Where $\Delta \ln I$ tour is a change in international tourism arrival; $\Delta \ln r o b$ is a change in the number of robberies in the Western Cape, $\Delta \operatorname{lngdp}$ is a change in economic growth; $\Delta$ lnune shows a change in the unemployment rate and $\Delta \operatorname{lnpros}$ represents a change in the prosecution rate in the Western Cape. Moreover, q represents the number of lags used in the model, while $\beta$ represents the coefficients to be estimated. Noteworthy is that an ARDL model was preferred as it provides a precise and detailed estimate. Furthermore, an ARDL model is the only model that accommodates a combination of variables that are integrated at level zero and one (Pesaran and Shin, 1999). It also allows researchers to estimate both the short-run and longrun relationship. After analyzing the short-run and long-run relationship, diagnostic tests were performed to check if the model used is free from serial correlation and heteroscedasticity.

\section{Empirical results and discussions}

The empirical presentation of results includes descriptive statistics, unit root test, cointegration approach, short-run analysis and post-estimation results. The subsequent section presents the descriptive statistics results.

\section{Descriptive analysis of the variables}

The descriptive statistics results are illustrated in table 1. The results show that the data used in this study is normally distributed and positively skewed. Furthermore, the descriptive statistics illustrate a high average in the number of international tourists, the number of car hijackers and robberies. This demonstrates that the crime rate in the Western Cape province is significantly high. Noteworthy is that there is a huge gap between the number of crimes committed and the number of prosecution. More so, the province is dominated by unemployment which is recorded at $30.1 \%$. This has led to the stagnant economic growth of $1 \%$.

\section{Unit root test analysis}

The Augmented Dickey Fuller unit root test results are shown in table 2. The results reveal that international tourism arrival, number of car hijacking and unemployment have p-values that are less than $10 \%$. This implies that the variables are stationary at level and are integrated at order zero. On the other hand, the number of robberies, economic growth and prosecution per population were found not to be stationary at level since their probability values were more than $10 \%$. Hence, the researcher first differenced the variables that were all stationary at order one. Zhanje and Garidzirai (2019) posit that if the variables are stationary at a different level, then an ARDL model is deemed fit. Thus, an ARDL model was used to determine if a long-run relationship exists among the variables.
Table 1. Analysis of Descriptive statistics (Source: Own Compilation)

\begin{tabular}{|l|c|c|c|c|c|c|}
\hline Descriptive & lnItour & lnhij & lnrob & Lnpros & lngdp & lnunem \\
\hline mean & 62.0361 & 20.2861 & 19.8421 & 8.1010 & 1.4491 & 24.1063 \\
\hline median & 30.6612 & 10.7818 & 9.8621 & 4.1128 & 0.1159 & 14.1263 \\
\hline maximum & 40.1590 & 11.4820 & 11.8810 & 5.8530 & 3.3210 & 30.1000 \\
\hline minimum & 21.8591 & 6.1295 & 6.0021 & 2.5103 & -1.1164 & 12.1752 \\
\hline Std.Dev & 3.1041 & 1.2037 & 1.1620 & 2.9862 & 1.1233 & 1.5181 \\
\hline Skewness & 0.9381 & 0.5827 & 0.3113 & 0.1986 & 0.8402 & 0.5123 \\
\hline Observation & 25 & 25 & 25 & 25 & 25 & 25 \\
\hline
\end{tabular}


Table 2. Unit root test results

(Source: Own Compilation from E-views; Note: $* * *$ represents 1 percent)

\begin{tabular}{|c|c|c|c|c|c|}
\hline \multirow{2}{*}{ Variables } & \multicolumn{2}{|c|}{ t-statistic and critical values } & \multicolumn{2}{|c|}{ Probabilities } & \multirow{2}{*}{$\begin{array}{l}\text { Order of } \\
\text { integration }\end{array}$} \\
\hline & Levels & $1^{\text {st }}$ Difference & Levels & $1^{\text {st }}$ Difference & \\
\hline $\ln \mathrm{I}$ & $-3.5110(-1.0)$ & $-3.7862(-2.1742)$ & $0.0029 * *$ & $0.0000^{*}$ & $\mathrm{I}(0)$ \\
\hline $\operatorname{lnhij}$ & -2.27 & $-2.7115(-2$ & $0.0000 * * *$ & & \\
\hline $\operatorname{lnro}$ & -1.1053 & $-5.2130(-3.95$ & 0.4098 & 0.0000 & In \\
\hline & -2.71 & -2.3 & 31 & $\overline{0.00}$ & \\
\hline $\operatorname{lng}$ & -2.83 & -3.9 & 64 & 0.0 & \\
\hline lnunem & $-1.1482(-3.1536)$ & $-1.3913(-2.8722)$ & $0.0038 * * *$ & $0.0000 * * *$ & $1(0)$ \\
\hline
\end{tabular}

\section{ARDL Bound tests analysis}

The ARDL bounds test results are illustrated in table 3. The results reveal that a calculated F-statistic of 4.1015 is greater than all the upper bound and lower bound values at all level of significance. Accordingly, the researcher rejected the null hypothesis of no cointegration and accepted that cointegration exists among the variables. Therefore, a long-run relationship was analyzed, and the results are shown in equation 3.

Since cointegration has been established, equation 3 shows a long-run relationship between the dependent variables and independent variables under the study:

$$
\text { lnitour }=0.1092-1.1821 \text { lnhij }-0.8631 \text { lnrob }+0.6972 \text { lnpros }+0.9828 \text { lngdp }-0.1072 \text { lnune }
$$

Equation 3 shows an inverse relationship between car hijacking and tourists arrival. Thus, a 1\% increase in car hijacking reduces the number of tourists by $1.18 \%$. The result was expected as it is in line with the routine activity theory (Cohen and Felson, 1979). The theory shares the notion that too many activities in the tourism sector increase crime activities in an area, causing the number of tourists to decrease. The results are also in line with the studies done by Matokovic and Matokovic (2019). The authors found that car hijacking is one of the feared crimes, as it reduces the number of tourists in a destination area. Robberies were also found to be significant at a $1 \%$ level, thereby negatively influencing the number of tourists in the Western Cape province. Thus, a $1 \%$ increase in robbery cases led to a $0.8631 \%$ decline in the number of tourists in the province. The same results were found by Mudzanani (2017), who found that robberies are a barrier to tourism arrivals in South Africa. Noteworthy is that all these crimes are a result of high unemployment in the country and province (Statistics South Africa, 2020). This is in line with the current study`s results that found an inverse relationship between unemployment and tourists arrival. A $1 \%$ increase in unemployment causes the crime rate to increase, which will reduce the number of tourists by $0.11 \%$. Prosecution per population was found to be significant and positively influencing the number of tourists. A $1 \%$ increase in prosecution per population increased the number of tourists by $0.70 \%$ in the Western Cape Province.

This result was expected and is in sync with the studies done by Garidzirai and Zhanje (2019). The authors concluded that prosecution per population decreases the crime rate, which increases the number of tourists inflow in Gauteng province. In addition, economic growth was found to be significant and positively related to the number of tourists in the province. Thus, a $1 \%$ increase in economic growth increases the number of tourists by $0.98 \%$. This is in line with the studies done by Manzoor et al., (2019) and Khan et al., (2020). Both studies found that economic growth attracts tourists in the country.

Table 4. Short-run analysis (Source: Authors compilation) Note: ** and *** represents 5 and 10 percent significant level

\begin{tabular}{|l|l|l|l|l|}
\hline Variable & Coefficient & Std.error & t-statistic & p-value \\
\hline ECT & -0.6195 & 0.2210 & -2.1010 & $0.0000^{* * *}$ \\
\hline Lnhij & 0.1061 & 0.4142 & 2.1762 & $0.0000^{* * *}$ \\
\hline Inrob & 0.9581 & 0.1360 & 3.7515 & $0.0000^{* * *}$ \\
\hline Inpros & -0.3167 & 0.9153 & -3.4291 & $0.0072^{* * *}$ \\
\hline lngdp & -0.1940 & 0.1025 & 2.1179 & 0.1827 \\
\hline lnune & -0.2719 & 0.9861 & -2.1011 & $0.0271^{* *}$ \\
\hline
\end{tabular}

\section{Diagnostic tests results}

Table 5 illustrates the diagnostic results. A p-value of 0.4578 on JB test means that the data used was normally distributed. This also confirms the results on the descriptive statistics. Moreover, the p-values of the white test, LM test and autocorrelation test are above $10 \%$, implying, the absence of heteroscedasticity, serial correlation and autocorrelation.

\section{CONCLUSION}

The tourism sector has undoubtedly contributed to economic growth, poverty alleviation, inequality and employment. The sector is currently fast-growing and its growth is intermingled with a high level of crime. To study this connection, the objective of the study was to examine the impact of crime on tourism arrival.

The study employed an Autoregressive distributive lag and found that the number of robberies and car hijacking cases negatively influence the number of tourists inflow in the Western Cape Province. The results imply tourism security is one of the crucial aspects when choosing a destination. In addition, unemployment negatively influences tourism arrival. Unemployment increases the crime rate and reduces the number of tourists in the Western Cape Province. On the other hand, economic growth and prosecution per population increased the number of tourists in a region. 
Based on the study`s results, the researcher recommends the creation of employment opportunities to minimize the crime rate in the province. The study further recommends that the government empower the province's residents with certain skills to equip those that are vulnerable and to avoid crime. Furthermore, the government should tighten the tourism sector's security so as to protect tourists. Even though the study achieved its objective, a limitation was identified. The study only focused on one province, the Western Cape Province. It is important to focus on all the provinces in South Africa, and this limitation can be addressed in future studies.

\section{REFERENCES}

Adekoya, A.F., \& Razak, N.A. (2017). The Dynamic Relationship between Crime and Economic Growth in Nigeria. International Journal of Management and Economics, 53(1), 47-64. https://doi.org/10.1515/ijme-2017-0004

Altindag, D. (2014). Crime and International Tourism. Journal of Labour Research, 35(1), 1-14. https://doi.org/10.1007/s12122-014-9174-8

Baker, D., \& Stockton, S. (2014). Tourism and Crime in America: A preliminary assessment of the relationship between the number of tourists and crime, two major American tourist cities. International Journal of Safety and Security in Tourism, 5(2), 1-25.

Biagi, B., Brandono, M.G., \& Detotto, C. (2012). The effect of tourism on crime in Italy: A dynamic panel approach. Economics, OpenAssessment, 6, 1-24. http://dx.doi.org/10.5018/economics-ejournal.ja.2012-25

Brás, M. (2015). Tourism and Crime - Why Tourists become Victims. Security \& Tourism: Local Policies and Practices. Conference held on 25th June 2015 at the Maison de L'Europe - European Union, Paris.

Cohen, L., \& Felson, M. (1979). Social Change and Crime Rate Trends: A Routine Activity Approach. American Sociological Review, 44(4), 588-608. https://doi.org/10.2307/2094589

Garidzirai, R., \& Nguza-Mduba, B. (2020). Does tourism contribute to local economic development (LED) in the City of Cape Town Municipality? A time series analysis. African Journal of Hospitality, Tourism and Leisure, 9(1), 1-13

Garidzirai, R., \& Moyo, C. (2020). Tourism, Poverty and Carbon Emissions in Newly Industrialized Countries. Journal of Environmental Management and Tourism, 11(3), 653-668. https://doi.org/10.14505//jemt.11.3(43).19

Garidzirai, R., \& Pasara, M.T. (2020). An analysis of the contribution of tourism on economic growth in South African provinces: a panel analysis. GeoJournal of Tourism and Geosites, 29(2), 554-564. https://doi.org/10.30892/gtg.29214-489

Gujarati, D. (2015). Econometrics, Palgrave Macmillan Education, London.

Kathena, I., \& Sheefeni, J., Sheefeni, P. (2017). The relationship between economic growth and crime rates in Namibia. European Journal of Basic and Economic Science, 4(1), 2017-2059.

Khan, A., Bibi, S, Lorenzo, A., Lyu, J \& Babar, Z.U. (2020) Tourism and Development in Developing Economies: A Policy Implication Perspective. Sustainability, 2020, 12, 1618. https://doi.org/10.3390/su12041618

Manzoor, F., Wei L., Asif, M., Haq, MZu, Rehman, Hu. (2019). The Contribution of Sustainable Tourism to Economic Growth and Employment in Pakistan. International Journal of Environmental Research and Public Health, 16(19), 3785. https://doi.org/10.3390/ijerph16193785

Mataković, H., \& Mataković, I.C. (2019). The impact of crime on security in tourism. Security defence quarterly, 25(5), 1-20. https://doi.org/10.35467/sdq/115539

Mudzanani, T.E. (2017). Examining newspaper articles on tourism and crime in South Africa. African Journal of Hospitality, Tourism and Leisure, 6(2), 1-8.

Nkosi, G.S. (2010).The impact of crime on tourism in the city of uMhlathuze, KwaZulu-Natal. South Asian Journal of Tourism and Heritage Studies, 3(2), 76-81.

Pasara, M.T., \& Garidzirai, R. (2020). Causality Effects among Gross Capital Formation, Unemployment and Economic Growth in South Africa. Economies, 8(1), 1-15. https://doi.org/10.3390/economies8020026

Pesaran, M.H., \& Shin, (1999). Bounds testing approaches to the analysis of level relationships. Journal of Applied Economics, 16(2), 289326. https://doi.org/10.1002/jae.616

Pizam, A., \& Mansfeld, Y. (2006). Toward a Theory of Tourism Security. In The Management of Hospitality and Tourism Enterprises, Tourism, Security and Safety, 1-27. https://doi.org/10.1016/B978-0-7506-7898-8.50004-7

Roncek, D.W., \& Maier, P.A. (1991). Bars, blocks, and crimes revisited: linking the theory of routine activities to the empiricism of "hot spots". Criminology, 29(4), 725-753. https://doi.org/10.1111/j.1745-9125.1991.tb01086.x

Troy, T., \& Jackman, M. (2013). Evaluating the Impact of Crime on Tourism in Barbados: A Transfer Function Approach. Tourism Analysis, 18, 193-191. https://doi.org/10.3727/108354213X13645733247774

Vila, B. (1994). A general paradigm for understanding criminal behavior: extending evolutionary ecological theory. Criminology, 32, 311360. https://doi.org/10.1111/j.1745-9125.1994.tb01157.x

Zhanje, S., \& Garidzirai, R. (2018). Export Performance and Foreign Direct Investment in Zimbabwe: An ARDL Approach. The 3rd Annual International Conference on Public Administration and Development Alternatives 04 - 06 July 2018, Stellenbosch University, Saldahna Bay, South Africa.

*** South African Police Services (2019). Crime statistics. (Accessed on 21 August 2020). https://www.saps.gov.za/services/crimestats.php

*** Statistics South Africa (2020). Category Archives: Crime. (Accessed on 20 July 2020). http://www.statssa.gov.za/?cat=26

*** World Bank (2019). World Bank Open data. (Accessed on 1 August 2020). https://data.worldbank.org/

*** World Tourism Organisation (2020). Tourism Statistics. (Accessed on 20 September 2020). https://www.e-unwto.org/toc/unwtotfb/current

Article history: Received: $30.10 .2020 \quad$ Revised: 06.02.2021 Accepted: 23.03.2021 Available online: 14.04 .2021 